\title{
Development of Seed Physiological Quality in Winter Oilseed Rape (Brassica napus L.) Cultivars
}

\author{
Kazem GHASEMI-GOLEZANI, Parisa SHEIKHZADEH-MOSADDEGH, Mohamad \\ Reza SHAKIBA, Abolghasem MOHAMADI, Safar NASROLLAHZADEH \\ University of Tabriz, Faculty of Agriculture, Department of Agronomy and Plant Breeding, Tabriz, Iran; golezani@gmail.com
}

\begin{abstract}
Stage of maturity at harvest is one of the most important factors that can influence the quality of seeds. This research was carried out in 2008- 2009 to evaluate the development of physiological seed quality in three winter oilseed rape (Brassica napus L.) cultivars ('Modena', 'Opera' and 'SLM ${ }_{046}$ '). Seeds were harvested serially in 9-10 stages during their development and maturation. Maximum seed weight (mass maturity) was achieved at 48-54 days after flowering, when seed moisture content was 41-50\%. However, maximum seed quality as measured by seed viability, germination percentage, germination rate and seedling dry weight was obtained 10 to 22 days after mass maturity. Thereafter, seed quality of all cultivars was started to decrease, due to ageing. Maximum germination rate of 'SLM ' ' and maximum seedling dry weight of 'Opera' were significantly higher than those of other two cultivars. These variations in seed quality parameters were attributed to differences in genetic constitution among oilseed rape cultivars. It was concluded that high quality seeds of winter oilseed rape cultivars could be produced with 14-16\% moisture content, which is suitable for direct and mechanical harvesting, threshing and storage without further drying.
\end{abstract}

Keywords: mass maturity, seed germination, seedling dry weight, seed viability

\section{Introduction}

Oilseed rape with $40-45 \%$ oil percentage is one of the valuable and important oil crops (Noori et al., 2007). High quality seed lots may improve grain yield of this crop in two ways: first because emergence of seedlings from the seedbed are rapid and uniform leading to the production of vigourous plants (Roberts and Osei-Bonsu, 1988; Ghassemi-Golezani, 1992; Begnami and Cortelazzo, 1996) and second because percentages of seedling emergence are high, so optimum stand establishment can be achieved under a wide range of environmental conditions (Perry, 1980). In addition, cold acclimation capability and winter survival of seedlings from good quality seeds are high, ensuring a satisfactory stand of winter crops (Ghassemi-Golezani et al., 2008a, b; 2009).

Stage of maturity at harvest is one of the most important factors that can influence the quality of seeds (Demir et al., 2008). Harvesting too early may result in low yield and quality, because of the partial development of essential structures of seeds (Keller and Kollmann, 1999; Elias and Copeland, 2001; Ekpong and Sukprakarn, 2008; Wang et al., 2008). Whereas, harvesting too late may increase the risk of shattering and decrease the quality of seeds due to ageing. Adverse environmental conditions such as raining may also result in sprouting of seeds on mother plants (Ellis and Pieta Filho, 1992; Elias and Copeland, 2001; Wang et al., 2008). Therefore, successful seed production depends on detection and implication of optimal time of harvesting. This time is a pre requisite for the production of maximum number of high quality seeds (Demir and Balkaya, 2005; Wang et al., 2008).

Maximum seed quality may be achieved at the end of seed filling period (Harington, 1972; Browne, 1978; Tekrony and Hunter, 1995; Tekrony and Egli, 1997) or slightly after this phase (Pieta Filho and Ellis, 1991; Ellis et al., 1993; Zanakis et al., 1994; Sanhewe and Ellis, 1996; Demir and Samit, 2001; Lehner et al., 2006; Ghassemi-Golezani and Mazloomi-Oskooyi, 2008; Ghassemi-Golezani and Hosseinzadeh-Mahootchy, 2009). The end of seed filling phase described as physiological maturity (Harington, 1972) or mass maturity (Ellis and Pieta Filho, 1992). Low quality of seeds can potentially decrease the rate and percentage of germination and seedling emergence, leading to poor stand establishment in the field and consequently yield loss in many crops such as corn (Cruz-Garcia et al., 1995; Moreno-Martinez et al., 1998), wheat (Ganguli and Sen-Mandi, 1990), cotton (Iqbal et al., 2002), barley (Copeland and Mc Donald, 2001; Samarah and Al-Kofahi, 2008) garden pea (Hampton and Scott, 1982). Therefore, it is necessary to examine and identify suitable techniques for production of high quality seeds from different crops. This research was carried out to investigate the changes in seed quality of winter rapeseed cultivars at different stages of development and maturity in order to determine the appropriate time for harvest and quality improvement. 


\section{Materials and methods}

An experiment was conducted to evaluate seed development and quality in winter oilseed rape cultivars at the Research Farm of the Faculty of Agriculture, University of Tabriz, Tabriz, Iran (Latitude $38^{\circ} 05^{\prime} \mathrm{N}$, Longitude $46^{\circ} 17^{\prime} \mathrm{E}$, Altitude $1360 \mathrm{~m}$ above sea level) in 2008 . The climate is characterized by mean annual precipitation of $245.75 \mathrm{~mm}$ per year, mean annual temperature of $10^{\circ} \mathrm{C}$, annual maximum temperature of $16.6^{\circ} \mathrm{C}$ and mean annual minimum temperature of $4.2^{\circ} \mathrm{C}$. Soil type is sandy loam with $\mathrm{EC}$ of $0.63 \mathrm{~d} / \mathrm{Sm}$ and $\mathrm{pH}$ of 8.1.

Seeds of three winter oilseed rape cultivars including 'Modena', 'Opera' and 'SLM ${ }_{046}$ ' were obtained from the Department of Oilseed Crops, Institute of Seed and Crop Breeding, Karaj, Iran. These seeds were treated with $2 \mathrm{~g} /$ $\mathrm{kg}$ Benomyl and then were sown by hand in about $1.5 \mathrm{~cm}$ with a density of 133 seeds per $\mathrm{m}^{2}$ in winter and decreased to 64 plants per $\mathrm{m}^{2}$ in spring 2009. Each plot consisted of 12 rows of $6 \mathrm{~m}$ length, spaced $25 \mathrm{~cm}$ apart. Experimental design was split plot, based on randomized complete block design with four replications. Cultivars were located in main plots and different harvests (9-10 stages) were assigned to sub plots. All plots were irrigated immediately after sowing and subsequent irrigations were carried out as required. Weeds were controlled by hand weeding during crop growth and development.

After seed formation, plants of $0.5 \mathrm{~m}^{2}$ from each plot were harvested at 9-10 stages. Then seeds were detached from the plots and seed moisture content was determined in accordance with ISTA rules (1985). Subsequently, seeds were ambient air dried at $20-24^{\circ} \mathrm{C}$, and 100 seed weight of each sample was determined. Seed samples within separate sealed bags were then placed in a refrigerator at $3-5^{\circ} \mathrm{C}$.

Seed quality tests were carried out at the Seed Technology Laboratory of the University of Tabriz. Four replicates of 25 seeds from each sample were tested for germination between moist rolled filter papers. The rolled papers with seeds were put into the plastic bags to avoid moisture loss. These rolled papers were incubated at $10^{\circ} \mathrm{C}$ for 10 days. Germination (protrusion of radicle by $2 \mathrm{~mm}$ ) was recorded in daily intervals. Seed germination rate for each treatment was calculated according to Ellis and Roberts (1980). At the end of each test the numbers of normal and abnormal seedlings were counted and percentages of viability and germination were calculated. Seedlings were then cut from the storage tissues and dried in an oven at $75^{\circ} \mathrm{C}$ for 24 hours and mean seedling dry weight for each replicate was determined.

Analysis of variance of the data appropriate to the experimental design and comparison of means at $\mathrm{P} \leq 0.05$ were carried out, using MSTATC software. Excel software was used to draw figures.

\section{Results}

In all cultivars, 100 seed weight increased with increasing days after flowering to a point where maximum weight was obtained (Fig. 1). After achieving the maximum weight (mass maturity), changes in seed weight was negligible. Maximum seed weights for 'SLM ${ }_{046}$ ' and 'Modena' were obtained at 53 and 54 days after flowering, respectively. However, Maximum seed weight of 'Opera' was achieved five- six days earlier than other cultivars. Mean seed weight of this cultivar was higher than that of 'Modena' and 'SLM ${ }_{046}$ ' at all stages of development and maturity. Whereas, the seed weight of 'Modena' was the lowest (Fig. 1).

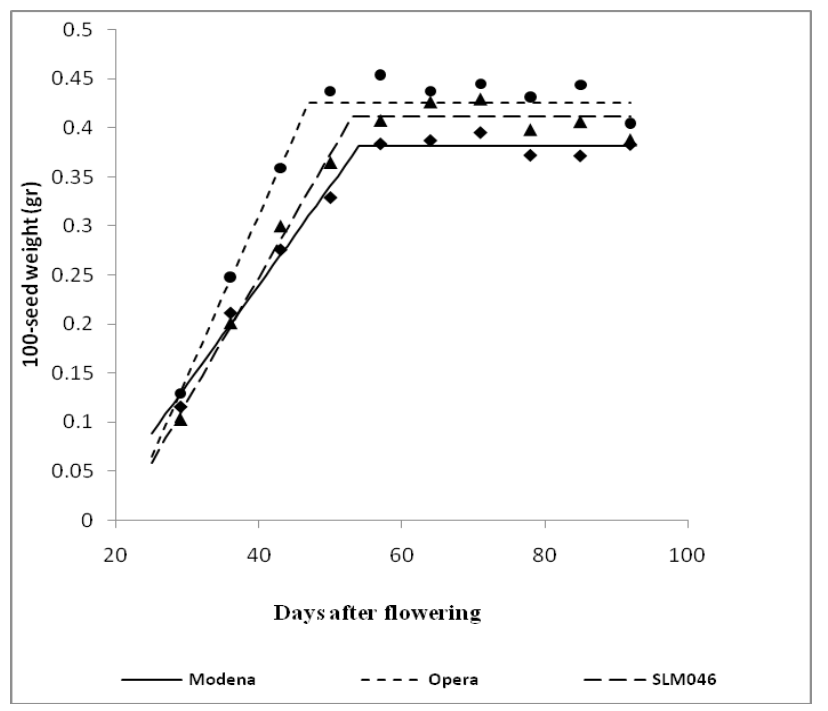

Fig. 1. Changes in 100 seed weight of three winter oilseed rape cultivars at different stages of seed development

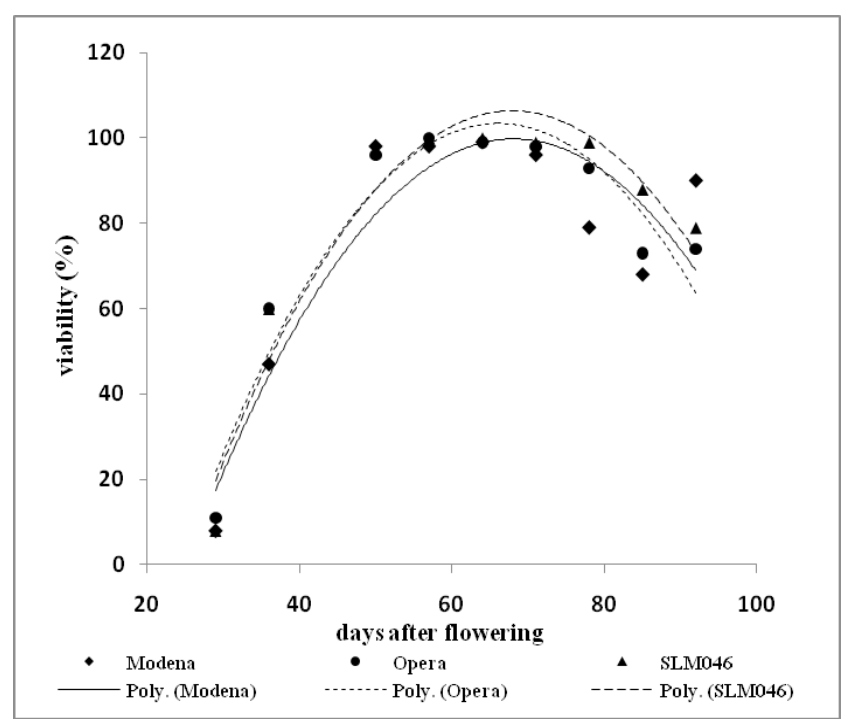

Fig. 2. Changes in seed viability of three winter oilseed rape cultivars at different stages of seed development 


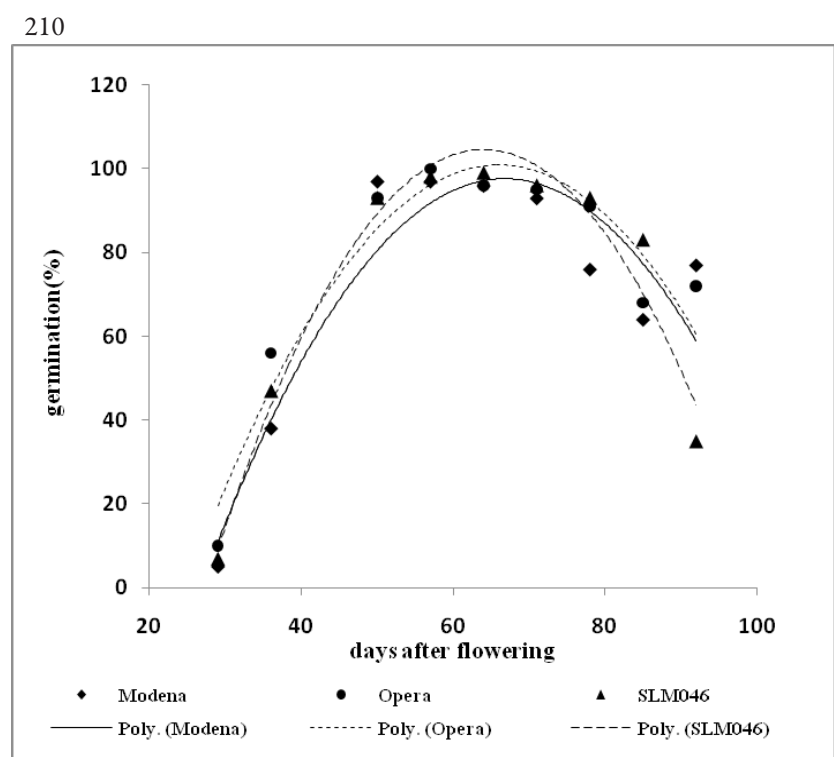

Fig. 3. Changes in percentage of seed germination of three winter oilseed rape cultivars at different stages of seed development

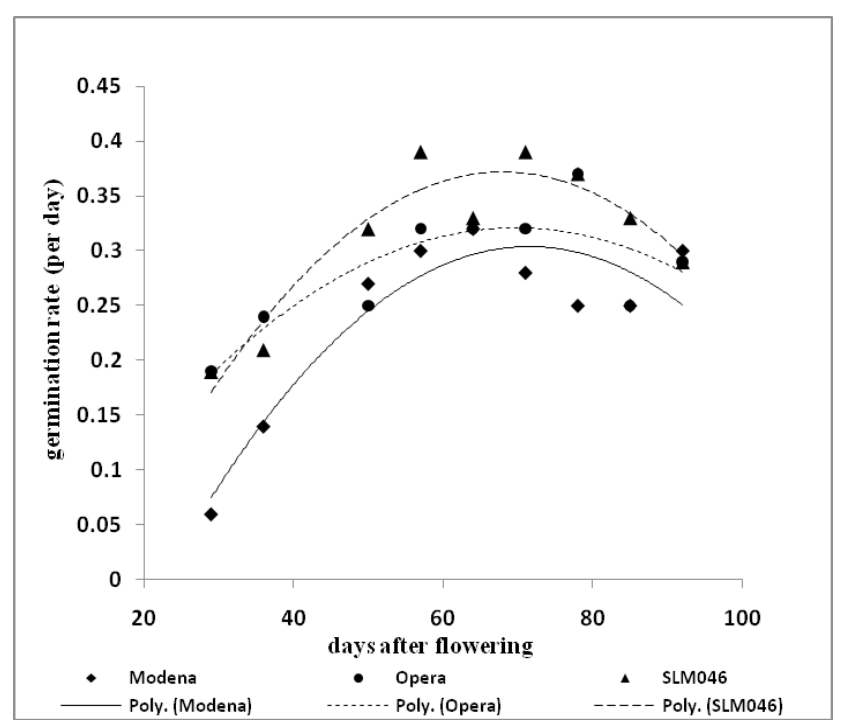

Fig. 4. Changes in germination rate of three winter oilseed rape cultivars at different stages of seed development

Seed viability of all three winter oilseed cultivars at early stages of seed filling was very low, but it was increased with progressing seed development (Fig. 2). This improvement continued until maximum seed viability was obtained at 68, 68 and 65 days after flowering for 'Modena', 'SLM ' ' and 'Opera', respectively. Thereafter, seed viability started to decrease (Fig. 2).

Seed germination enhanced as a result of seed development. Maximum percentage of seed germination for 'SLM ${ }_{046}$ ', 'Modena' and 'Opera' was achieved at 63, 66 and 66 days after flowering, respectively. After that, percentage of seed germination started to decrease. Reduction of seed germination percentage for 'SLM ${ }_{046}$ ' was fast and started earlier than that for other cultivars (Fig. 3).

Germination rate of winter oilseed rape cultivars increased with increasing days after flowering up to the max-

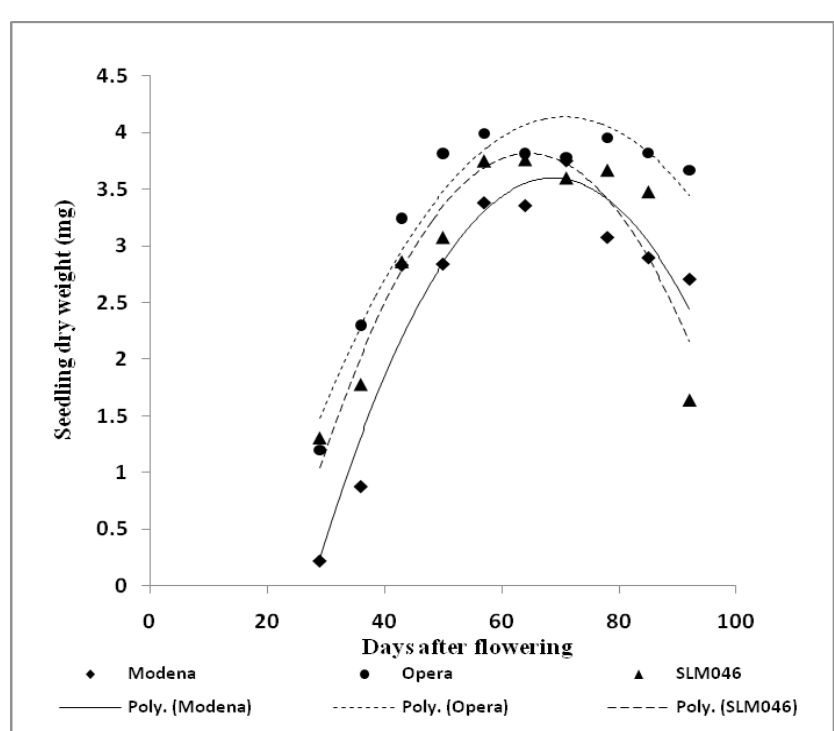

Fig. 5. Changes in seedling dry weight of three winter oilseed rape cultivars at different stages of seed development

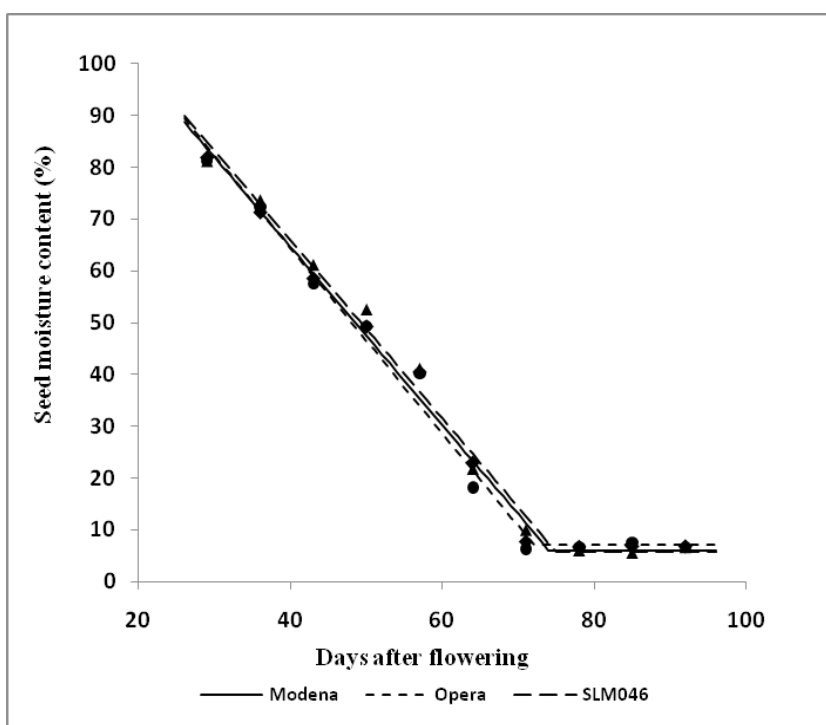

Fig. 6. Changes in seed moisture content of three winter oilseed rape cultivars at different stages of seed development

imum point. Thereafter, rate of germination of all cultivars gradually decreased. Maximum germination rate was achieved at 67, 69 and 70 days after flowering for ' $\mathrm{SLM}_{046}$ ', 'Opera' and 'Modena', respectively (Fig. 4).

Seedling dry weights of all cultivars increased progressively with seed development up to 64,68 and 70 days after flowering for 'SLM ' ' 'Modena' and 'Opera', respectively. Then, seedling dry weights started to decrease with increasing days after flowering. This reduction for 'Opera' was occurred six and two days later than that for, 'SLM ${ }_{046}$ ' and 'Modena', respectively. Reduction of seedling dry weight for 'Opera' at later stages of seed development was also slower than that for other cultivars (Fig. 5).

Seed moisture content for all winter oilseed rape cultivars at early stages of seed development was very high, but decreased with increasing days after flowering. Seed mois- 
ture content at mass maturity was about $41,43.5$ and $50 \%$ for 'Modena', 'SLM 046 ' and 'Opera', respectively (Fig. 6).

Analysis of variance of the data for maximum seed weight and other quality parameters showed that cultivar had only significant effects maximum germination rate $(\mathrm{P} \leq 0.05)$ and seedling dry weight $(\mathrm{P} \leq 0.01)$. The highest germination rate and seedling dry weight was recorded for 'SLM ${ }_{046}$ ' and 'Opera', respectively (Tab. 1).

\section{Discussion}

Tab. 1. Comparison of means of maximum germination rate and seedling dry weight of three winter oilseed rape cultivars

\begin{tabular}{|c|c|c|}
\hline Cultivar & $\begin{array}{l}\text { Germination } \\
\text { rate (per day) }\end{array}$ & $\begin{array}{l}\text { Seedling dry } \\
\text { weight }(\mathrm{mg})\end{array}$ \\
\hline 'Modena' & $0.309 \mathrm{~b}$ & $3.700 \mathrm{~b}$ \\
\hline 'Opera' & $0.326 \mathrm{~b}$ & $4.145 \mathrm{a}$ \\
\hline 'SLM ${ }_{046}^{\prime}$ & $0.373 \mathrm{a}$ & $3.845 \mathrm{~b}$ \\
\hline
\end{tabular}

Different letters in each column indicate significant difference at $P \leq 0.05$

Seed maturation in oilseed rape is an important process during which morphological (seed size and color), physiological (dry weight, moisture content and germination), chemical (oil, protein and carbohydrate) and functional (vigor and viability) changes occur from the time of fertilization until the seeds are ready for harvest (Şeker, 2002; Demir and Balkaya, 2005). Maximum seed weight (mass maturity) occurred at 48-54 days after flowering, depending on cultivar (Fig. 1). However, maximum seed quality as measured by seed viability, germination percentage, germination rate and seedling dry weight was obtained 10 to 22 days after mass maturity (Fig. 2, 3, 4 and 5). These results contradict the suggestions that seed quality is maximum at the end of the seed filling phase (Harington, 1972; Browne, 1978; Tekrony and Hunter, 1995; Tekrony and Egli, 1997), but are in agreement with those reported for rice (Ellis et al., 1993), wheat (Lehner et al., 2006), tomato (Demir and Samit, 2001; Demir et al., 2008), common been (Ghassemi-Golezani and Mazloomi-Oskooyi, 2008) and faba been (Ghassemi-Golezani and HosseinzadehMahootchy, 2009). Low seed quality at the early stages of seed development was due to immaturity, while the decline in quality parameters at later stages (Fig. 2, 3, 4 and 5) caused by seed aging on mother plant (GhassemiGolezani and Mazloomi-Oskooyi, 2008).

Significant differences in germination rate and seedling dry weight among oilseed rape cultivars (Tab. 1) can be attributed to variation in genetic constitution, which may strongly influence seed vigour (Perry, 1980; GhassemiGolezani et al., 2010). Field performance of high vigor seeds are much better than that of low vigor seeds, ensuring rapid, uniform and satisfactory stand establishment under a wide range of environmental conditions (Hampton and Scott, 1982; Ghassemi-Golezani et al., 1996a, b; 2008b).

Seed moisture content of winter oilseed rape cultivars at mass maturity stage was high (41-50\%), similar to that reported for wheat (37-39\%) (Schnyder and Baum, 1992; Calderini et al., 2000), maize (35-36\%) (Egli and Tekrony, 1997; Borras and Westgate, 2006), soybean (60\%) (Fraser et al., 1982) and sunflower (38\%) (Rondanini et al., 2007). However, maximum seed quality of winter oilseed rape cultivars was obtained 10 to 22 days after mass maturity, depending on cultivar and quality test (Fig. 2, 3, 4 and 5).

\section{Conclusions}

In general, seed quality of oilseed rape cultivars was high at moisture contents of $14-16 \%$, which is suitable for direct and mechanical harvesting, threshing and storage without further drying.

\section{References}

Begnami CN, Cortelazzo AL (1996). Cellular alterations during accelerated aging of French bean seeds. Seed Sci Tech 24:295-303.

Borras L, Westgate ME (2006). Predicting maize kernel sink capacity early in development. Field Crops Res 95:223-233.

Browne CL (1978). Identification of physiological maturity in sunflower (Helianthus annuus). Austr J Agricul Animal Husbandry 18:282-286.

Calderini DF, Abeledo LG, Slafer GA (2000). Physiological maturity in wheat based on kernel water and dry matter. Agron J 92:895-901.

Copeland LO, Mc Donald MB (2001). Seed vigour and vigour tests, p. 121-144. In: Copeland LO, Mc Donald MB (Eds.). Principles of Seed Science and Technology, $4^{\text {th }}$ Edn. Kluwer Academic Publishing Group.

Cruz-Garcia F, Gonzal-Hernandez VA, Molina-Moreno J, Vazquez-Ramos JM (1995). Seed deterioration and respiration as related to DNA metabolism in germinating maize. Seed Sci Tech 23:477-486.

Demir I, Ashirov AM, Mavi K (2008). Effect of seed production environment and time of harvest on tomato (Lycopersicon esculentum) seedling growth. Res J Seed Sci 1:1-10.

Demir I, Balkaya A (2005). Seed development stages of kale (Brassica oleracea var. acephala L.) genotypes in Turkey. Hort Sci 32:147-153.

Demir I, Samit Y (2001). Seed quality in relation to fruit maturation and seed dry weight during development in tomato. Seed Sci Tech 29:453-462.

Egli DB, Tekrony DM (1997). Species differences in seed water status during seed maturation and germination. Seed Sci Res $7: 3-11$.

Ekpong B, Sukprakarn S (2008). Seed physiological maturity in dill (Anethum graveolens L.). Kasetsart J 42:1-6.

Elias SG, Copeland LO (2001). Physiological and harvest maturity of canola in relation to seed quality. Agron J 93:1054-1058.

Ellis RH, Hong TD, Jackson MT (1993). Seed production environment, time of harvest and potential longevity of seeds of three cultivars of rice (Oryza sativa L.). Annals Bot 72:583-590. 
212

Ellis RH, Pieta Filho C (1992). Seed development and cereal seed longevity. Seed Sci Res 3:247-257.

Ellis RH, Roberts EH (1980). Towards a rational basis for testing seed quality, p. 605-635. In: Hebblethwaite PD (Ed.). Seed production. Butterworths, London.

Fraser J, Egli DB, Leggett JE (1982). Pod and seed development in soybean cultivars with differences in seed size. Agron J 74:81-85.

Ganguli S, Sen-Mandi S (1990). Some physiological differences between naturally and artificially aged wheat seeds. Seed Sci Tech 18:507-514.

Ghassemi-Golezani K (1992). Effects of seed quality on cereal yields. Univesity of Reading, UK, PhD Thesis.

Ghassemi-Golezani K, Hosseinzadeh-Mahootchy A (2009). Changes in seed vigour of faba bean (Vicia faba L.) cultivars during development and maturity. Seed Sci Tech 37:713720 .

Ghassemi-Golezani K, Khomari S, Dalil B, HosseinzadehMahootchy A, Chadordooz-Jeddi A (2010). Effects of seed aging on field performance of winter oilseed rape. J Food, Agric Environ 8:175-178.

Ghassemi-Golezani K, Khomari S, Valizadeh M (2009). Effects of seed and seedling vigour on antioxidative isozyme activity and cold acclimation capability of winter oilseed rape. Journal of Food, Agriculture and Environment 7:452-456.

Ghassemi-Golezani K, Khomari S, Valizadeh M, Alyari H (2008a). Changes in chlorophyll content and fluorescence of leaves of winter rapeseed affected by seedling vigour and cold acclimation duration. J Food, Agric Environ 7:196199.

Ghassemi-Golezani K, Khomari S, Valizadeh M, Alyari H (2008b). Effects of seed vigour and the duration of cold acclimation on freezing tolerance of winter oilseed rape. Seed Sci Tech 36:767-775.

Ghassemi-Golezani K, Mazloomi-Oskooyi R (2008). Effect of water supply on seed quality development in common bean (Phaseolus vulgaris var.). Internat J Plant Prod 2:117-124.

Ghassemi-Golezani K, Nasrollahzadeh S, Rahimzadeh Khoyi F, Moghaddam M (1996b). Effects of seed development and maturation on wheat seed quality under irrigated and nonirrigated conditions. Agricult Sci 6:99-117.

Ghassemi-Golezani K, Salehian H, Rahimzadeh Khoyi F, Moghaddam M (1996a). Effect of seed vigour on seedling emergence and grain yield of wheat in the field. J Agricult Sci Natural Resour 3:48-55.

Hampton JG, Scott DJ (1982). Effect of seed vigour on garden pea production. New Zealand J Agricult Res 25:289-294.

Harington JF (1972). Seed storage and longevity, p. 145-245. In: Kozlowski TT (Ed.). Seed Biology. Academic Press, New York.

International Seed Testing Association [ISTA] (1985). International Rules for Seed Testing. Seed Sci Tech13: 338.

Iqbal N, Basra SHMA, Rehman K (2002). Evaluation of vigour and oil quality in cottonseed during accelerated aging. Internatio J o Agricult Biol 4:318-322.
Keller M, Kollmann J (1999). Effects of seed provenance on germination of herb for agricultural compensation sited. Agricult, Ecosystem Environ 72:87-99.

Lehner A, Bailly C, Flechel B, Poels P, Comea D, Corbineau $F$ (2006). Changes in wheat seed germination ability, soluble carbohydrate and antioxidant enzyme activities in the embryo during the desiccation phase of matuiration. J Cereal Sci 43:175-182.

Moreno-Martinez E, Vazquez-Badillo ME, Rivera A, Navarrete R, Fasquivel-Villagrana F (1998). Effect of seed shape and size on germination of corn (Zea mays L.) stored under adverse conditions. Seed Sci Tech 26:439-448.

Noori AS, Khalaj H, Shirazi Rad H, Alahdadi I (2007). Investigation of seed vigour and germination of canola cultivars under less irrigation in padding stage and after it. Pakistan J Biol Sci 10:2880-2884.

Perry DA (1980). The concept of seed vigour and its relevance to seed production techniaues, p. 585-591. In: Hebblethwaite PD (Ed.). Seed production, Butterworths, London.

Pieta Filho C, Ellis RH (1991). The development of seed quality in spring barley in four environments. I. Germination and longevity. Seed Sci Res 1:163-177.

Roberts EH, Osei-Bonsu K (1988). Seed and seedling vigour, p. 897-910. In: Summerfield RJ (Ed.). Word crop: cool season food legumes, London.

Rondanini DP, Savin R, Hall AJ (2007). Estimation of physiological maturity in sunflower as a function of fruit water concentration. European J Agron 26:295-309.

Samara NH, Al-Kofahi S (2008). Relationship of seed quality tests to field emergence of artificial aged barley seeds in the semiarid Mediterranean region. Jordan J Agricult Sci

Sanhewe AJ, Ellis RH (1996). Seed development and maturation in Phaseolus ulgaris. II. Post-harvest longevity in air-dry storage. J Experim Bot 47:959-965.

Schnyder H, Baum U (1992). Growth of the grain of wheat (Triticum aestivum L.). The relationship between water content and dry matter accumulation. European J Agron 1:51-57.

Şeker H (2002). Seed maturation in soybean (Glycine max L.). Ataturk University, Ziraat Faculties Dergisi 33:221-227.

Tekrony DM, Egli DB (1997). Accumulation of seed vigour during development and maturation, p. 369-384. In: Ellis RH, Black M, Murdoch AJ, Hong TD (Eds.). Basic and applied aspects of seed biology, Dordercht: Kluwer Academic Publishers.

Tekrony DM, Hunter JL (1995). Effect of seed maturation and genotype on seed vigour in maize. Crop Sci 35:857-862.

Wang Y, Mu C, Hou Y, Li X (2008). Optimum harvest time of Vicia cracca in relation to high seed quality during pod development. Crop Sci48:709-715.

Zanakis G, Ellis RH, Summerfield RJ (1994). Seed quality in relation to seed development and maturation in three genotypes of soybean (Glycine max). Experimen Agricult 30:139-156. 